\title{
Infantile onset spinocerebellar ataxia
}

INSERM

\section{Source}

INSERM. (1999). Orphanet: an online rare disease and orphan drug data base. Infantile onset spinocerebellar ataxia. ORPHA:1186

Infantile-onset spinocerebellar ataxia (IOSCA) is a hereditary neurological disorder with early and severe involvement of both the peripheral and central nervous systems. It has only been described in Finnish families. 